\title{
An Innovative Solid-State Micro-Anaerobic Digestion Process to Valorize Food Waste: Technical Development Constraints and Consequences on Biological Performances
}

\author{
Axelle Degueurce ${ }^{1}$ D $\cdot$ Patrick Dabert ${ }^{1} \cdot$ Victor Argence $^{1} \cdot$ Laurent Blondel $^{1} \cdot$ Anne Le Bihan $^{1} \cdot$ Megane Lebreton $^{1}$. \\ Pascal Peu ${ }^{1} \cdot$ Martine Sarrazin $^{1} \cdot$ Sylvie Picard ${ }^{1}$. Anne Trémier ${ }^{1}$
}

Received: 4 November 2020 / Accepted: 23 May 2021 / Published online: 18 August 2021

(c) The Author(s) 2021

\begin{abstract}
To face the increase of waste production and meet the energy demand of urban areas, municipal waste management systems should be rethought. Innovative solutions such as decentralised small-scale anaerobic digestion could be developed. This work presents the design, operation and performances of a new micro-scale anaerobic digester (AD) developed to degrade food waste (FW) in urban areas i.e. highly compact and with low water and energy demand. To meet these objectives, the new micro-scale AD is a semi-continuous and two-stage process built vertically to take advantage of the gravity to mix and move the digested matter instead of using mechanical devices. The first stage consists in a tubular reactor fed weekly with FW and periodically watered with leachate from the second stage reactor located below the tubular reactor. Results show that AD performances were highly correlated to the efficiency of hydric transfer between the tubular reactor and the leachate tank. Indeed, $\mathrm{pH}$, volatile fatty acids and microbial community analysis showed that the hydrolysis occurred in the tubular reactor, while the methanogenesis step occurred in the leachate tank. Overall, the average methane production was $143 \pm 87$ ${ }_{\mathrm{N}} \mathrm{L} / \mathrm{kg}_{\mathrm{vs}}$ with an average methane content of $44 \pm 10 \%$ and the operation mode of the process has still to be improved.
\end{abstract}

\section{Graphic Abstract}

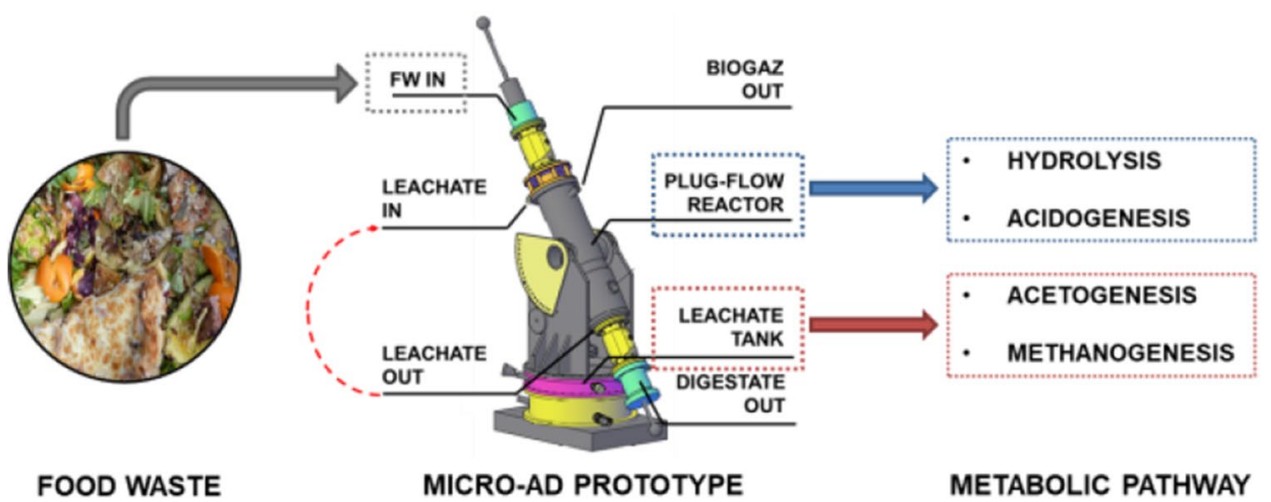

Keywords Two-stage $\cdot$ Semi-continuous $\cdot$ Leachate recirculation $\cdot$ Trace elements $\cdot$ Methanogenic pathways $\cdot$ NGS

Axelle Degueurce

axelle.degueurce@inrae.fr

1 INRAE, UR OPAALE, 17 av. de Cucillé, CS 64427, Rennes 35044, France

\section{Statement of Novelty}

Interest in anaerobic digestion of FW in urban areas is increasing. The development of such strategy implies a size reduction of anaerobic digestion technologies and thus innovative solutions to comply with anaerobic digestion process 
requirements. In this article a new technology is presented as well as the assessment of one and a half year of operation.

\section{Introduction}

From year 2018 to 2050, the urban population of European countries is expected to increase from 74 to $83 \%$ of the total population [1]. This growing urbanization will result in an increasing energetic and food demand and produce high amount of municipal solid waste putting environmental, economic and social pressure on the urban centers [2]. In Europe, the organic fraction of household waste represents between 14 and $47 \%$ of the total amount of waste produced [3]. A part of that organic fraction, such as papers and cardboards, is efficiently recycled while the valorisation of biowaste (food leftovers, vegetable peels, etc.) could be improved. In order to decrease the cities' environmental impacts and to contribute to a better resilience of urban areas, waste management systems have to be rethought. In this objective, biowaste proximity management with microscale system are expected to led to better involvement of waste producers in the sorting and valorization of their biowaste, with less impacts of collection. Moreover, this new management scale can complete existing treatment equipment for new quarters in growing cities. Among other tools, new decentralized systems based on micro-scale anaerobic digestion (micro-scale AD) technologies could be a solution to locally valorize biowaste, produce energy and provide fertilizer to urban farming.

Anaerobic digestion is the biological process of organic matter biodegradation in absence of oxygen. It results in the mineralization of complex organic molecules into a biogas composed of methane and carbon dioxide and to a residue called digestate. $\mathrm{AD}$ is traditionally divided into four metabolic steps [4, 5]. Hydrolysis and acidogenesis involve hundreds of fermentative Bacteria that degrade complex organic matter such as carbohydrates, long chain fatty acids and proteins into volatile fatty acids (VFA). Acetogenesis is performed by bacterial groups that produce acetate either by fermentation of simple carbohydrates, amino acids or VFA, or by carbon dioxide reduction [6]. Finally, methanogenesis is the metabolic process of methane production that is performed by the Archaea microorganisms and is usually divided into the acetoclastic pathway when methane is produced from acetate and the hydrogenotrophic pathway when methane is produced from hydrogen and carbon dioxide. A third metabolic pathway is sometime distinguished as methane production from methylated compounds [7]. VFA and hydrogen concentrations are key factors of successful methanogenesis since their accumulation can induce AD inhibition and their use leads the methanogenic pathway used by the community $[4,8]$.
Micro-scale AD development and study started during the 1970s in China and India [9] where about 30 million anaerobic digesters are nowadays installed to meet basic energy needs of rural farm families $[10,11]$. Depending on climate conditions, geographical situation and type of waste treated, three main technologies are used: the fixed dome digester, the floating drum digester and the plug flow or tubular digester [12]. All of them are very simple and rustic systems that do not contain neither heating nor stirring devices in order to save energy and avoid maintenance. Again, with the objective of simplicity and effectiveness, digesters are often buried to use natural insulation of soil and limit temperature variations. Biogas produced can be used in its raw form through direct combustion for cooking and heating or to feed combined heat and power (CHP) units, biogas lamps or gas-powered refrigerators [12].

Even if micro-scale AD fills basic energy needs of many families, its rusticity causes several disadvantages. Because of a lack of knowledge, the digestion process is not stable and produces low energy yields compared to the theoretical maximum potential. Consequently, digesters require low loading rates, increased volumes (between 1 and $150 \mathrm{~m}^{3}$ ) and show slow recovery after failure. Temperature variation is often reported to be the main factor influencing AD instability $[12,13]$. Consequently, in temperate countries, these micro-scale $\mathrm{AD}$ technologies seem to be difficult to replicate as they are. Moreover, in those systems, biogas leakage is a major problem which increases environmental impacts and fire explosion risk in households [12].

However, after improving the above listed technical and environmental weaknesses, the development of simple and affordable micro-scale $\mathrm{AD}$ processes may have potential to contribute meeting the energy needs of urban areas in temperate countries. A first example was performed in Midwestern United States, where a modified and completely buried fixed-dome digester was installed inside a greenhouse [10]. Results showed that the ambient and digester temperatures ranged between -13.5 to $35{ }^{\circ} \mathrm{C}$ and 5.3 to $27.9{ }^{\circ} \mathrm{C}$ respectively along a year, which highlights the positive effect of burying the digester to limit temperature variations of the process. However, AD was efficiently performed only during half time of the year when the temperature inside the digester was over $20^{\circ} \mathrm{C}$. During the coldest period, the digestion was inhibited. These results suggest that, in temperate countries, digesters should be heated to stabilize biogas production during winter time. A second work, performed in London, gave more stable methane production yields with a more complex system including a breaker-mill, a pre-digester and a completely stirred tank reactor also installed under a greenhouse [14]. However, the electrical production was only sufficient to run the plant itself because of the use of many electrical devices (stirrer, pumps, mill, heater, etc.) 
that used about $150 \mathrm{~W}$ of power against a production of $151 \mathrm{~W}$ considering a biogas valorization with a CHP unit.

According to the previous cited work, the development of new micro-scale $\mathrm{AD}$ technologies is required to address the main constraints linked to biowaste typology, land pressure and energy saving. In France, food waste (FW) represent about $25 \%$ of the total municipal solid waste stream which makes it the most important substrate in terms of quantity and sustained availability of urban areas [15]. The average total solid (TS) content of this substrate is of $28.4 \pm 9.8 \%$ in Europe [16] leading to the choice of developing a solidstate anaerobic digestion (SSAD) process. In addition, with the objective of proposing a sustainable technology, limiting water addition also supports the choice of using a SSAD process. The second level of consideration concerns the limitation of using pre-treatments on-site to lower energy consumption and increase the technology compactness. To avoid the addition of sorting and shredding steps usually performed in AD plants, the new technology should be able to deal with raw FW that may contain inert impurities (e.g. plastic particles, bones, shells, etc.) and large particles (e.g. entire fruits and vegetables). Also, to limit FW storage and avoid odor releases on-site, the substrate should be rapidly fed in the reactor, which implies the use of a semi-continuous technology. However, a phase separation step of the digestate seems to be unavoidable in order to further valorize and hygienize the solid part, but also to limit extra-costs if transport of the digestate inside or outside the urban area is necessary. On the other hand, the liquid fraction of the digestate could be recycled in the process. This phase separation should be integrated to the technology without any mechanical device addition to meet the objective of limiting energy demand and surface area need.

In this context, this work aims at proposing a new microscale AD technology for urban biowaste, as simple as possible (following the example of Chinese's or Indian's ones) but adapted to temperate countries that comply with the requirements of EU and national safety, sanitary and environmental legislations that are stricter than those of developing countries. The design and startup of the process are described for the first 15 months of running both from process performances and underlying microbial community.

\section{Materials and Methods}

\section{Process Development}

\section{Design of the Micro-Scale AD Technology}

Figure 1 presents the micro-scale AD technology which consists in a semi-continuous solid state anaerobic digester divided into two parts. The first part is a tubular reactor of
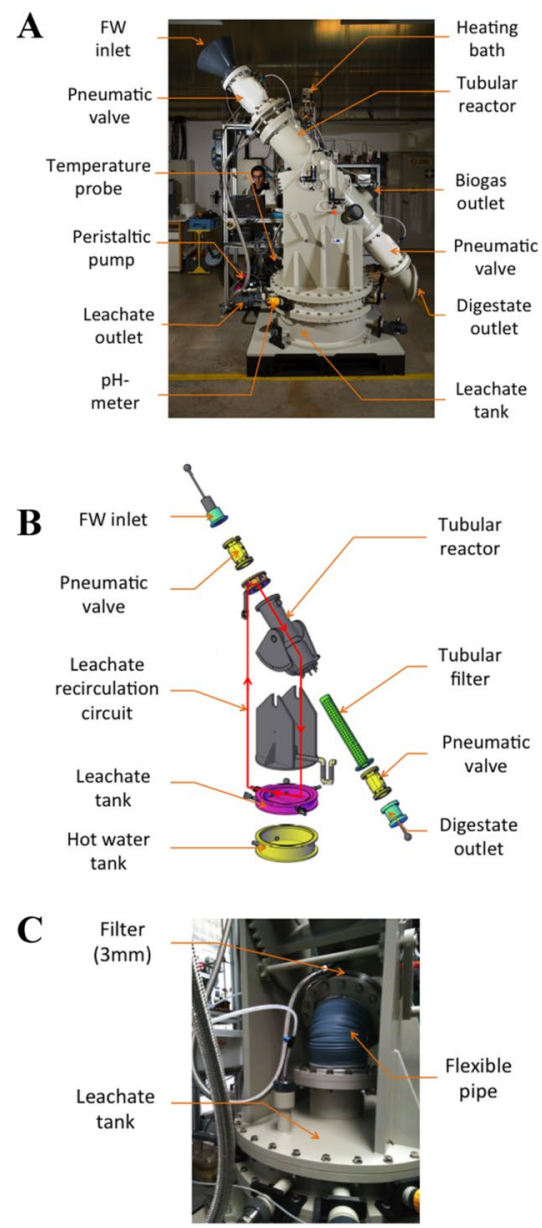

D

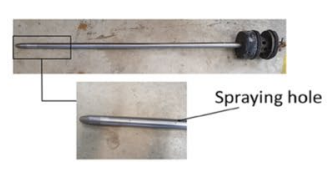

Fig. 1 Diagram of the micro-scale AD prototype

$20 \mathrm{~L}$ containing a tubular filter of variable sieve diameters (between 10 and $4 \mathrm{~mm}$ from the top to the bottom) (Fig. 1b). The tubular filter holds the food waste to be degraded. With an internal diameter of $20 \mathrm{~cm}$, this tubular filter is wide enough to allow the introduction of heterogeneous FW with large particles (pineapples heads, entire potatoes, apples...) or impurities without blocking the system. The second part consists of a cylindrical tank of $48.7 \mathrm{~L}$ that contains the liquid inoculum called leachate. The two parts are linked to each other with two airtight flexible pipes. The first pipe, equipped with another $3 \mathrm{~mm}$ sieve filter, connects the bottom of the tubular reactor to the top of the leachate tank (Fig. 1c). The second pipe connects the bottom side of the leachate tank to the top of the tubular reactor and is equipped with a peristaltic pump (Fig. 1a). In that way, the leachate tank, the tubular filter, the two flexible pipes and the peristaltic 
pump form a leachate recirculation circuit (Fig. 1b). The leachate recirculation circuit can be improved by adding a removable spraying stick (Fig. 1d) in the middle of the FW loaded inside the tubular reactor. That stick covers about three quarter of the tubular filter's length. Every $8 \mathrm{~cm}$, three holes spaced $120^{\circ}$ from each other were drilled to ensure watering efficiency of the raw and digested FW in all directions once connected to the recirculation circuit.

Both tubular and leachate tanks are double-walled reactors that allow the circulation of hot water to heat the system. Each part has its own heating system that can be handled independently from each other. The leachate tank is equipped with a probe that continuously measures the temperature of the leachate. The temperature in the tubular reactor is not measured internally but controlled with the temperature of the hot water circulating in the double-wall.

Pneumatic valves at the inlet and outlet of the tubular reactor ensure hermetic closure of the system and provide anaerobic conditions to the process. Biogas outlets are located at the bottom of the tubular reactor and at the top of the leachate tank.

\section{Micro-Scale AD Operation}

During the feeding phase, the tubular reactor is tilted into a complete horizontal position at human height. Then, two feeding methods can be used. The first method involves the use of a large syringe-like system. The syringe is filled with FW and introduced into the FW inlet of the tubular reactor. When pushing the piston of the syringe, FW is loaded in the tubular filter and pushes out the extra solid digestate from the other side of the tubular reactor. The second method uses cylindrical perforated capsules (length: $30 \mathrm{~cm}$; diameter: $13 \mathrm{~cm}$ ) presented in Fig. 2. FW is loaded into the capsules that are themselves loaded into the tubular filter. The capsules were designed so that four of them fit simultaneously inside the tubular reactor, which as the advantage

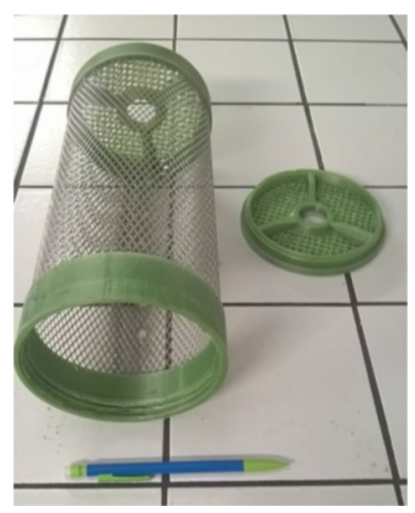

Fig. 2 Picture of one capsule used to feed the micro-scale AD prototype along periods 2 and 3 of setting precisely the solid retention time (SRT). At each feeding event, the new capsule that is loaded at the top of the tubular reactor pushes out the capsule located at the bottom side of the tubular reactor. The perforations of capsules allow the transfer of small organic particles from one capsule to another and finally to the leachate tank during the AD process.

Once loaded and during anaerobic digestion process, the reactor is straightened to an angle of $35^{\circ}$ from the vertical position. This position ensures energy savings as the solid fraction moves from the top of the reactor to the bottom with gravity instead of mechanic devices.

Periodically, leachate is homogenized by injecting biogas in the leachate tank for few minutes with the peristaltic pump. Then, leachate is recirculated inside the tubular filter, to pass through the raw and digested FW and catch solubilized organic matter from the solid that is partly degraded. The organic matter captured is filtered at $3 \mathrm{~mm}$ thanks to the $1.5 \mathrm{~cm}$ thick filter located before the collecting pipe of the leachate tank (Fig. 1c) before going back to the leachate tank reactor to remove large particles and avoid clogging of the leachate recirculation system. The particles trapped on the filter continue their degradation until they are small enough to get in the leachate tank. A valve at the bottom of the leachate tank allows the removal of extra-leachate produced during the $\mathrm{AD}$ process.

\section{Experimental Plan}

A start-up phase and three feeding strategies were experimented overtime (Table 1). The start-up phase consisted in feeding the prototype with a digestate from an industrial plant treating mainly biowaste from supermarkets (about $23,000 \mathrm{t} / \mathrm{y}$ ). The leachate tank was filled with about $48 \mathrm{~L}$ of the liquid digestate from that plant and about $5 \mathrm{~kg}$ of the solid fraction of the same digestate was fed in the tubular reactor. In addition, $1 \mathrm{~kg}$ of fresh FW from a nearby collective restaurant, with composition specified in Table 2, was loaded at the top of the tubular reactor. After 2 weeks, when residual organic matter present in the liquid and solid digestate was completely degraded, and biogas production had stabilized, the feeding phase started.

The targeted solid retention time was 4 weeks. Thus, once a week, the reactor was fed with about $3 \mathrm{~kg}$ of fresh FW from the same nearby collective restaurant than the FW used for the start-up phase. This loading rate ensures a solid to inoculum ratio (S/I) of $4\left(\mathrm{~kg}_{\mathrm{ww}} / \mathrm{kg}_{\mathrm{ww}}\right.$ where WW stands for "wet weight") which was found optimal in preliminary experiments (data not shown). In terms of volatile solid (VS), the $\mathrm{S} / \mathrm{I}$ ratio was $7.4 \pm 3.2\left(\mathrm{~kg}_{\mathrm{vs}} / \mathrm{kg}_{\mathrm{vs}}\right)$ depending on the experimental week considered. The hydraulic retention time (HRT) of the leachate was not clearly set and depended on the experimental conditions. However, to meet the objective 
Table 1 Summary of the AD parameters, protocol changes and issues encountered depending on the experimental period

\begin{tabular}{|c|c|c|c|c|}
\hline Period & $\mathrm{AD}$ parameters & Week & Prototype or protocol adjustment & Encountered issues \\
\hline Start-up & $\begin{array}{l}\text { - No feeding } \\
\text { - No discharge }\end{array}$ & $1-2$ & & \\
\hline \multirow[t]{5}{*}{ Period 1} & \multirow{5}{*}{$\begin{array}{l}\text { - Feeding frequency: once a week } \\
\text { - Leachate recirculation: } \\
\text { Volume }=12 \mathrm{~L} \\
\text { Frequency }=1 / 24 \mathrm{~h} \\
\text { - SRT: not determined } \\
\text { - HRT }=356 \text { days } \\
\text { - S/I }=7.4 \pm 3.2(\mathrm{kgVS} / \mathrm{kgVS})\end{array}$} & $3-6$ & $\begin{array}{l}\text { Feeding performed with the syringe tech- } \\
\text { nique }\end{array}$ & Digestate stuck in the tubular reactor \\
\hline & & $7-11$ & $\begin{array}{l}\text { Weekly collection of } 2 \mathrm{~kg} \text { of solid digestate } \\
\text { by hand }\end{array}$ & Lack of FW watering in the tubular reactor \\
\hline & & $12-13$ & Addition of a spraying stick & \\
\hline & & $14-15$ & & Annual lab closure \\
\hline & & $16-22$ & & \\
\hline \multirow[t]{6}{*}{ Period 2} & \multirow{6}{*}{$\begin{array}{l}\text { - Feeding frequency: once a week } \\
\text { - Leachate recirculation: variable } \\
\text { - SRT }=4 \text { weeks } \\
\text { - HRT }=560 \text { days } \\
\text { - } \mathrm{S} / \mathrm{I}=7.4 \pm 3.2(\mathrm{kgVS} / \mathrm{kgVS})\end{array}$} & $23-25$ & $\begin{array}{l}\text { Feeding performed with the capsule tech- } \\
\text { nique }\end{array}$ & \\
\hline & & $26-29$ & $\begin{array}{l}\text { Change of recirculation parameters: } \mathrm{V}=24 \\
\mathrm{~L} ; \mathrm{F}=1 / 24 \mathrm{~h}\end{array}$ & \\
\hline & & $30-33$ & $\begin{array}{l}\text { Change of recirculation parameters: } \mathrm{V}=12 \\
\mathrm{~L} ; \mathrm{F}=1 / 36 \mathrm{~h}\end{array}$ & \\
\hline & & $34-38$ & $\begin{array}{l}\text { - Back to recirculation parameters of period } 1 \\
\text { - Nutrient addition at the beginning of week } \\
34\end{array}$ & \\
\hline & & $39-43$ & & Biogas leackage \\
\hline & & $44-49$ & & \\
\hline Period 3 & $\begin{array}{l}\text { - Feeding frequency: once a week } \\
\text { - SRT }=4 \text { weeks } \\
\text { - HRT }=560 \text { days } \\
-\mathrm{S} / \mathrm{I}=7.4 \pm 3.2(\mathrm{kgVS} / \mathrm{kgVS})\end{array}$ & $50-64$ & $\begin{array}{l}\text { FW was shredded before being loaded into } \\
\text { a capsule }\end{array}$ & \\
\hline
\end{tabular}

Table 2 Physical-chemical characteristics of micro-scale AD prototype inputs: (i) digestate from the industrial AD unit, (ii) leachate from the industrial AD unit and (iii) average values of all FW samples collected during the experiment $(n=62)$

\begin{tabular}{|c|c|c|c|c|c|c|c|c|}
\hline Substrate & $\mathrm{pH}$ & $\mathrm{TS} \mathrm{g} / \mathrm{kg}_{\mathrm{ww}}$ & VS $\mathrm{g} / \mathrm{kg}_{\mathrm{TS}}$ & COD $\mathrm{g} / \mathrm{kg}_{\mathrm{ww}}$ & $\mathrm{NH}_{4} \mathrm{gN} / \mathrm{kg}_{\mathrm{ww}}$ & $\mathrm{TKN}$ gN/ $\mathrm{kg}_{\mathrm{ww}}$ & \multicolumn{2}{|c|}{$\begin{array}{l}\text { Bacteria Archaea } 16 \mathrm{~S} \\
\text { rDNA/g or mL }\end{array}$} \\
\hline Leachate & 8.0 & $47 \pm 1$ & $651 \pm 4$ & $50 \pm 1$ & $4.4 \pm 0.0$ & $6.7 \pm 0.1$ & $5.5 \times 10^{8}$ & $1.3 \times 10^{6}$ \\
\hline Digestate & - & $470 \pm 10$ & $781 \pm 11$ & $548 \pm 162$ & $2.5 \pm 0.0$ & $8.7 \pm 0.2$ & $1.8 \times 10^{10}$ & $1.4 \times 10^{7}$ \\
\hline $\mathrm{FW}(\mathrm{n}=62)$ & $5.3 \pm 0.4$ & $196 \pm 52$ & $931 \pm 21$ & $276 \pm 86$ & $0.1 \pm 0.2$ & $6.4 \pm 2.9$ & - & - \\
\hline
\end{tabular}

of low water addition and production, the HRT should be as long as possible.

The three feeding strategies defined three experimental periods described below (Table 1):

- Period 1: from week 3 to 22 Feeding was performed with the syringe-like system. During that period, SRT was not clearly set and defined as the quantity of digestate discharged varied each week. The leachate collection was also variable depending on the week considered. However, the mean HRT of that period was 356 days.

- Period 2: from week 23 to 49 Feeding was performed with the perforated capsule technique. In this way, the SRT of the FW was set to 4 weeks (one capsule per week). Each week, about $600 \mathrm{~mL}$ of leachate were collected which corresponds to a HRT of 560 days.
- Period 3: from week 50 to 64 Feeding was performed with the perforated capsule technique but FW was shredded into pieces lower than $1 \mathrm{~cm}$ with an industrial cooking shredder (Robot Coupe ${ }^{\circledR} \mathrm{R} 15$ V.V.) prior to its loading. At the beginning of period 3, content of all capsules was shredded and reloaded in the micro-scale AD prototype. As the use of capsule continued, the SRT remained the same than during the second period, i.e. 4 weeks. In a consistent manner, the same protocol for leachate collection was applied which corresponds to a HRT of 560 days.

Along the experiment and every $24 \mathrm{~h}, 12 \mathrm{~L}$ of leachate were recirculated during $5 \mathrm{~min}$. The entire trial lasted 64 weeks and was run at $39^{\circ} \mathrm{C}$ both in the leachate tank and in the tubular reactor. However, depending on AD 
performances, prototype or protocol adjustments were performed that are summarized in Table 1. These changes will be presented and discussed along the results and discussion section.

When needed, a nutrient solution was added to the leachate tank. Indeed, according to the literature, trace elements (TE) such as cobalt, iron, nickel, molybdenum and selenium are mandatory for AD microorganisms [17-20] and especially for mono-digestion of FW [20]. The nutrient solution was prepared with a powder of $\mathrm{FeCl}_{3}(345 \mathrm{mgFe} / \mathrm{g})$ and several standard solutions with a concentration of $10 \mathrm{mg} / \mathrm{L}$ of the following elements: Co, Ni, Mo and Se. Depending on the leachate concentration of each TE, the nutrient solution was prepared to reach the optimal range found in the literature (see Table 3).

\section{Physical-Chemical Analysis}

After weekly sampling, fresh FW and solid digestate were ground to pieces lower than $0.5 \mathrm{~cm}$ with a cooking shredder (Robot Coupe ${ }^{\circledR}$ R 15 V.V.) and stored at $-20^{\circ} \mathrm{C}$. Total solids (TS) and volatile solids (VS) were measured on wet and ground samples, directly after sampling, using standard methods [21]. TKN and total ammonia nitrogen concentrations were determined by distillation (TKN after mineralization) on defrosted samples [22]. Chemical organic demand (COD) of FW and solid digestate was quantified by Mohr's salt dosage (after mineralisation) on dried and finely ground samples according to the manufacturer's instruction (855 Robotic Titrosampler, Metrohm). COD of leachate was measured on diluted samples using the same method than solid samples. The volatile fatty acid (VFA) content (acetate, propionate, butyrate, isobutyrate, isovalerate, lactate and succinate) were analyzed by high performance liquid chromatography (HPLC) [23]. The analysis was performed on the aqueous extract of solid samples (1:1 mass ratio; mixing: 15 min; centrifugation: $20 \mathrm{~min}, 9000 \mathrm{rpm}, 4{ }^{\circ} \mathrm{C}$ ) and raw leachate. $\mathrm{pH}$ of the leachate was continuously monitored in the leachate tank while the FOS/TAC ratio was measured every two days. $\mathrm{pH}$ of solid samples was also measured on their aqueous extracts. The average values of initial FW physical-chemical characteristics are given in Table 2.
Biogas production rate was monitored continuously at standard temperature and pressure conditions with a volumic gas meter. Biogas composition and content (methane, carbon dioxide and punctually, hydrogen) were analysed by gas chromatography (GC) every 2 days (Lucas et al., 2007).

\section{Microbial Community Monitoring}

\section{DNA Extraction}

Total DNA extractions were performed starting with 250-500 mg of frozen ground digestate or leachate pellet obtained by centrifugation of $2 \mathrm{~mL}$ raw leachate at $4{ }^{\circ} \mathrm{C}$ and $12,100 \mathrm{rpm}$ for $20 \mathrm{~min}$. The Macherey-Nagel NucleoSpin® Soil kit was used according to manufacturer's instructions. Final DNA elution was done in $60 \mu \mathrm{L}$ of elution buffer. Concentration and quality of the extracted DNA were checked respectively by spectrophotometry with an Eppendorf BioPhotometer® D30 and $0.7 \%$ agarose gel electrophoresis in Tris acetate EDTA (TAE 1X) buffer. Extracted DNA were then stored at $-20{ }^{\circ} \mathrm{C}$ until further analyses.

\section{Bacterial and Archaeal Quantification}

The total Bacteria, total Archaea and the hydrogenotrophic methanogen Methanobacteriales were quantified by realtime qPCR targeting their $16 \mathrm{~S}$ rRNA gene $[24,25]$. The acetotrophic methanogens were quantified by real-time qPCR targeting the specific acas gene [26]. PCR amplifications were carried out in a $25 \mu \mathrm{L}$ final working volume using the iQ SYBR Green Supermix 2X (Bio-Rad) and the CFX96 thermal cycler (BioRad) according to supplier's instructions. Protocols are detailed in the Supplementary material. Amplifications were made in triplicate on 10 and 100-fold diluted DNA for 45 amplification cycles. A melting curve analysis was performed to check the specificity of the amplification and primer dimer formation. The gene copy numbers were calculated by comparison with DNA standards of known concentration amplified in the same runs and expressed as gene copy number per $g$ of solid digestate or $\mathrm{mL}$ of raw leachate.
Table 3 Optimal TE content in the literature compared to TE content in the leachate tank before and after nutrient solution supplementation $(\mathrm{mg} / \mathrm{L})$

\begin{tabular}{lllll}
\hline & $\begin{array}{l}\text { Range of optimal } \\
\text { concentration }^{\mathrm{a}}\end{array}$ & $\begin{array}{l}\text { Concentration of the } \\
\text { nutrient solution }\end{array}$ & $\begin{array}{l}\text { Concentration before } \\
\text { supplementation }\end{array}$ & $\begin{array}{l}\text { Concentration after } \\
\text { supplementation }\end{array}$ \\
\hline Cobalt & $0.05-10$ & 180.2 & $<0.05$ & 2.9 \\
Iron & $5-500$ & 8494 & 12 & 220 \\
Nickel & $0.0272-5$ & 178.6 & 0.1 & 3.4 \\
Molybdenum & $0.035-10$ & 90.5 & 0.1 & 1.9 \\
Selenium & $0.056-0.2$ & 7.5 & $<0.01$ & 0.1 \\
\hline
\end{tabular}

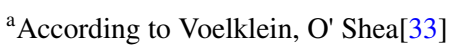




\section{Microbial Community Characterization}

Bacterial and archaeal community characterization was performed by the INRAE PROSE Research Unit (Antony, France) on an Ion Torrent ${ }^{\mathrm{TM}}$ PGM (Life Technologies, USA) platform as described in detail in the Supplementary material. The analysis targeted the V4-V5 variable regions of the bacterial and archaeal 16S rRNA genes using fusion primers derived from primers $515 \mathrm{~F}$ ( $5^{\prime}$-CTGYCAGCMGCCGCG GTA-3') [27] and 928R (5'-CCCCGYCAATTCMTTTRAG T-3') [28]. The sequencing produced an average of 15350 reads of about 420 base pairs length for each sample. These sequences were processed (primers trimming, chimera and singleton removal, clustering in operational taxonomic units (OTUs) at $97 \%$ of sequence similarity and taxonomic affiliation) with the FROGS pipeline [29] of the MIGALE bioinformatics platform of the French National Research Institute for Agriculture, Food, and the Environment Galaxy portal (INRAE Jouy-en-Josas, France). Taxonomic affiliation of the OTUs was done both by BLAST (NCBI, http://www. ncbi.nlm.nih.gov/BLAST) and Ribosomal Database Project II (https://rdp.cme.msu.edu/) sequence alignment. Diversity indexes calculation and comparison were performed using a shiny web interface of the phyloseq package of the R software [30].

\section{Statistical Analysis}

One-way analysis of variance (ANOVA) method was used to set the significance of different parameters variations along experiments. The degree of freedom between groups is denoted Df1 and the degree of freedom within groups is denoted Df2. The results of ANOVA are presented between brackets in the results section using the following annotation: $\mathrm{F}$ (Df1, Df2) $=\mathrm{F}$ value, $\mathrm{p}<0.05$.

\section{Results and Discussion}

\section{Process Performances}

\section{Start-Up Phase}

Methane production of the micro-scale AD prototype along the entire experiment is presented in Fig. 3. During the start-up phase, i.e. the first two weeks, methane production reached its highest level with an average of $1168 \pm 329 \mathrm{~L} /$ $\mathrm{kg}_{\mathrm{vs}}$. During this period, the prototype mostly contained digestate (liquid and solid fractions) from the industrial AD plant treating FW and the methane production recorded is attributed to the remaining organic matter present in both

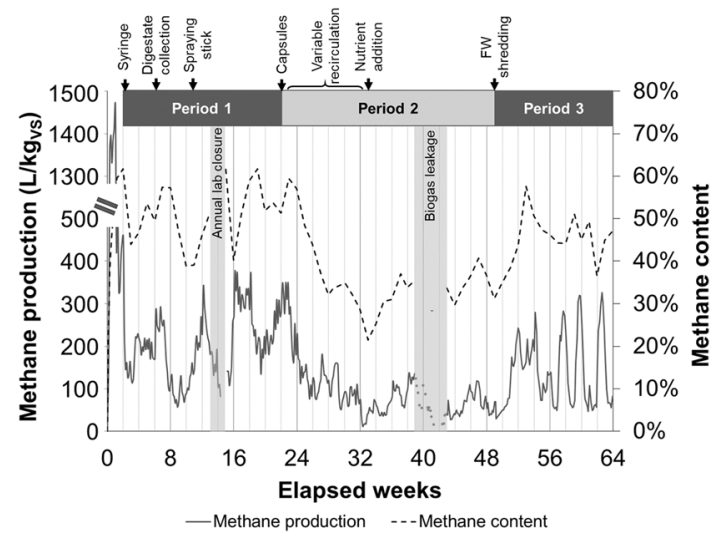

Fig. 3 Variation of methane production and methane content for the micro-scale AD prototype (Period 1: No capsules-no shredding; Period 2: Capsules—no shredding; Period 3: Capsules—shredding)

Table 4 Comparative performances of micro-scale AD prototype depending on the experimental conditions

\begin{tabular}{llcll}
\hline & $\begin{array}{l}\text { Average biogas } \\
\text { production }\left({ }_{\mathrm{N}} \mathrm{L} /\right. \\
\left.\mathrm{kg}_{\mathrm{vS}}\right)\end{array}$ & $\begin{array}{l}\text { Average meth- } \\
\text { ane production } \\
\left({ }_{\mathrm{N}} \mathrm{L} / \mathrm{kg}_{\mathrm{VS}}\right)\end{array}$ & $\begin{array}{l}\text { Methane } \\
\text { content } \\
(\%)\end{array}$ & $\begin{array}{l}\mathrm{VS} \\
\text { removal } \\
(\%)\end{array}$ \\
\hline Period 1 & $466 \pm 163$ & $200 \pm 78$ & $51 \pm 7$ & 57 \\
Period 2 & $308 \pm 135$ & $97 \pm 67$ & $36 \pm 9$ & 26 \\
Period 3 & $445 \pm 266$ & $145 \pm 82$ & $45 \pm 6$ & 52 \\
All periods & $418 \pm 198$ & $143 \pm 87$ & $44 \pm 10$ & 49 \\
\hline
\end{tabular}

fractions of this digestate. When all the remaining organic matter was degraded, methane production decreased and feeding of the prototype with fresh FW started.

\section{Period 1: Learning About the Micro-Scale AD Prototype}

The first period started at the end of the 2 nd week and lasted until the end of the 22nd week. During this period, feeding was performed using the syringe-like system. Methane production varied between 57 and $377 \mathrm{~L} / \mathrm{kg}_{\mathrm{vs}}$ with an average of $200 \pm 78{ }_{\mathrm{N}} \mathrm{L} / \mathrm{kg}_{\mathrm{vs}}$ and methane content varied between 39 and $62 \%$ with an average of $51 \pm 7 \%$ (Table 4 ). Two main protocol adjustments can explain these variations. First, solid digestate was not pushed out the reactor with the feeding system as expected and was thus stuck at the bottom of the reactor for the first 6 weeks. As a result, weekly average of methane production gradually increased from $151 \pm 26$ $\mathrm{L} / \mathrm{kg}_{\mathrm{vs}}$ during the $3 \mathrm{rd}$ week to $190 \pm 26 \mathrm{~L} / \mathrm{kg}_{\mathrm{vs}}$ during the 6th week, which was due to an increase of the solid retention time in the tubular reactor. At the beginning of the 7th week, solid digestate was removed by hand at the bottom of the tubular reactor until enough volume was recovered to load the new batch of FW. From that day, about $2 \mathrm{~kg}$ of solid digestate were collected by hand every week. As a 
consequence, for 5 weeks after that event, methane production decreased and remained low $\left(108 \pm 31 \mathrm{~L} / \mathrm{kg}_{\mathrm{vs}}\right)$. A visual control of recirculation efficiency at the top of the tubular reactor showed that, because of sauces, creamy products and small particles size (rice, semolina) of FW leftovers, fresh FW rapidly turned into a pasty-like material and was thus impermeable to leachate. The lack of watering probably resulted in low degradation performances of $\mathrm{FW}$ and low methane yields which led to the second protocol adjustment at the beginning of the 12th week. That week, the removable spraying stick was added to the leachate recirculation system As a result, methane production and methane content increased from the beginning of week 12 until the end of the first period Fig. 3), in spite of the disturbance due to the lab

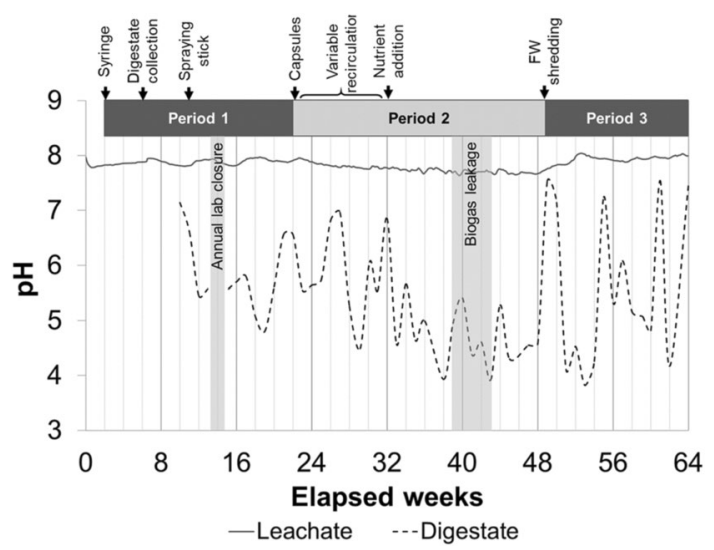

Fig. $4 \mathrm{pH}$ variations of digestate and leachate (Period 1: No capsules—no shredding; Period 2: Capsules—no shredding; Period 3: Capsules—-shredding) closure during weeks 14 and 15 . Indeed, methane production and methane content respectively increased from $171 \pm 74$ to $221 \pm 75 \mathrm{~L} / \mathrm{kg}_{\mathrm{vs}}$ and from $48 \pm 7 \%$ to $53 \pm 7 \%$ compared to the first 11 weeks, proving that enhancing watering significantly improved methane production performances $(\mathrm{F}(1$, $133)=14, \mathrm{p}<0.05$ and $\mathrm{F}(1,42)=37, \mathrm{p}<0.05$ respectively).

$\mathrm{pH}$ variation of the digestate and leachate along the experiment are presented in Fig. 4. During this first period, the $\mathrm{pH}$ of the digestate was very unstable with an average of $5.9 \pm 0.8$ suggesting that methanogenesis may be inhibited in the tubular reactor [19]. In addition, total VFA content in the digestate was high with a value of $10.2 \pm 4.2 \mathrm{~g} / \mathrm{kg}_{\mathrm{ww}}$ and a large diversity of components (mainly acetate, propionate, butyrate and lactate) (Table 5A). On the opposite, $\mathrm{pH}$ of the leachate was very stable and closer to neutrality with an average value of $7.9 \pm 0.0$. Total VFA content was also much lower than in the digestate with a mean value of $2.0 \pm 1.9 \mathrm{~g} / \mathrm{kg}_{\mathrm{ww}}$ (Table 5B). All together, these data suggest that the hydrolysis and acidogenesis steps of AD took place in the tubular reactor while the methanogenesis step probably occurred in the leachate tank. Moreover, the difference in VFA concentrations is probably due to a poor efficiency in the hydric transfer between the tubular reactor and the leachate tank, as the VFAs present in the solid digestate were not properly transferred to the leachate tank where methanogenesis occurred.

These hypotheses were confirmed by the bacterial and archaeal concentrations measured by real-time qPCR of $16 \mathrm{~S}$ rRNA genes (Fig. 5). At the start of the process the number of bacteria in the digestate increased by 3.8 -fold from $1.8 \times 10^{10} 16 \mathrm{~S}$ rRNA gene $\mathrm{g}^{-1}$ to $6.9 \times 10^{10} 16 \mathrm{~S}$ rRNA gene $\mathrm{g}^{-1}$ during the 7 weeks when digestate remained blocked

Table 5 Comparative physical-chemical characteristics and VFA content of the digestate (A) and the leachate (B) depending on the experimental conditions

\begin{tabular}{|c|c|c|c|c|c|c|c|c|c|}
\hline \multicolumn{10}{|c|}{ A. Digestate } \\
\hline & $\begin{array}{l}\text { TS } \\
\left(\mathrm{g} / \mathrm{kg}_{\mathrm{wW}}\right)\end{array}$ & $\begin{array}{l}\text { VS } \\
\text { (g/kgTS) }\end{array}$ & $\begin{array}{l}\mathrm{TKN} \\
\left(\mathrm{gN} / \mathrm{kg}_{\mathrm{wW}}\right)\end{array}$ & $\begin{array}{l}\mathrm{NH}_{4}^{+} \\
\left(\mathrm{gN} / \mathrm{kg}_{\mathrm{wW}}\right)\end{array}$ & $\begin{array}{l}\text { Acetate } \\
\left(\mathrm{g} / \mathrm{kg}_{\mathrm{wW}}\right)\end{array}$ & $\begin{array}{l}\text { Propionate } \\
\left(\mathrm{g} / \mathrm{kg}_{\mathrm{ww}}\right)\end{array}$ & $\begin{array}{l}\text { Butyrate } \\
\left(\mathrm{g} / \mathrm{kg}_{\mathrm{WW}}\right)\end{array}$ & $\begin{array}{l}\text { Lactate } \\
\left(\mathrm{g} / \mathrm{kg}_{\mathrm{wW}}\right)\end{array}$ & $\begin{array}{l}\text { Total VFA } \\
\left(\mathrm{g} / \mathrm{kg}_{\mathrm{WW}}\right)\end{array}$ \\
\hline Period 1 & $199 \pm 59$ & $859 \pm 57$ & $9.2 \pm 1.4$ & $3.9 \pm 2.0$ & $2.9 \pm 1.6$ & $1.5 \pm 0.5$ & $3.0 \pm 2.2$ & $1.6 \pm 1.3$ & $10.2 \pm 4.2$ \\
\hline Period 2 & $154 \pm 44$ & $910 \pm 32$ & $9.6 \pm 3.2$ & $3.4 \pm 1.2$ & $2.4 \pm 1.0$ & $0.6 \pm 0.3$ & $1.3 \pm 0.9$ & $3.8 \pm 3.8$ & $8.4 \pm 4.4$ \\
\hline Period 3 & $146 \pm 37$ & $887 \pm 56$ & $7.8 \pm 1.3$ & $2.6 \pm 0.9$ & $2.2 \pm 1.5$ & $0.5 \pm 0.4$ & $1.5 \pm 1.2$ & $4.1 \pm 5.1$ & $9.0 \pm 5.7$ \\
\hline Total & $161 \pm 50$ & $891 \pm 49$ & $9.0 \pm 2.5$ & $3.3 \pm 1.1$ & $2.5 \pm 1.3$ & $0.7 \pm 0.5$ & $1.7 \pm 1.4$ & $3.4 \pm 3.9$ & $9.0 \pm 4.6$ \\
\hline \multicolumn{10}{|c|}{ B. Leachate } \\
\hline & $\begin{array}{l}\text { TS } \\
\left(\mathrm{g} / \mathrm{kg}_{\mathrm{WW}}\right)\end{array}$ & $\begin{array}{l}\text { VS } \\
(\mathrm{g} / \mathrm{kgTS})\end{array}$ & $\begin{array}{l}\text { TKN } \\
\left(\mathrm{gN} / \mathrm{kg}_{\mathrm{WW}}\right)\end{array}$ & $\begin{array}{l}\mathrm{NH}_{4}^{+} \\
\left(\mathrm{gN} / \mathrm{kg}_{\mathrm{WW}}\right)\end{array}$ & $\begin{array}{l}\text { Acetate } \\
\left(\mathrm{g} / \mathrm{kg}_{\mathrm{WW}}\right)\end{array}$ & $\begin{array}{l}\text { Propionate } \\
\left(\mathrm{g} / \mathrm{kg}_{\mathrm{WW}}\right)\end{array}$ & $\begin{array}{l}\text { Butyrate } \\
\left(\mathrm{g} / \mathrm{kg}_{\mathrm{WW}}\right)\end{array}$ & $\begin{array}{l}\text { Lactate } \\
\left(\mathrm{g} / \mathrm{kg}_{\mathrm{WW}}\right)\end{array}$ & $\begin{array}{l}\text { Total VFA } \\
\left(\mathrm{g} / \mathrm{kg}_{\mathrm{WW}}\right)\end{array}$ \\
\hline Period 1 & $17 \pm 2$ & $478 \pm 45$ & $5.3 \pm 0.2$ & $4.7 \pm 0.3$ & $1.6 \pm 1.5$ & $0.2 \pm 0.2$ & 0.0 & 0.0 & $2.0 \pm 1.9$ \\
\hline Period 2 & $16 \pm 1$ & $388 \pm 50$ & $4.2 \pm 0.7$ & $3.8 \pm 0.6$ & $0.6 \pm 0.7$ & $0.4 \pm 0.5$ & 0.0 & 0.0 & $0.7 \pm 0.8$ \\
\hline Period 3 & $15 \pm 1$ & $362 \pm 34$ & $3.2 \pm 0.2$ & $2.8 \pm 0.1$ & $0.9 \pm 0.7$ & $0.1 \pm 0.2$ & 0.0 & 0.0 & $1.3 \pm 1.0$ \\
\hline Total & $16 \pm 1$ & $395 \pm 57$ & $4.0 \pm 0.9$ & $3.6 \pm 0.8$ & $0.9 \pm 1.1$ & $0.2 \pm 0.3$ & 0.0 & 0.0 & $9.0 \pm 4.6$ \\
\hline
\end{tabular}




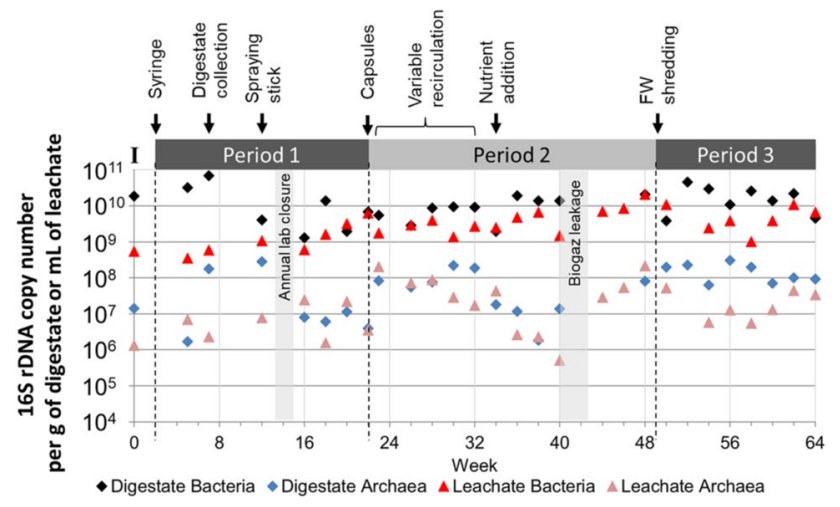

Fig. 5 Real time qPCR quantification of total Bacteria and Archaea in digestate and leachate (a), and of the acetoclastic (Acas) and hydrogenotrophic (Mbt) methanogens in digestate (b) and leachate (c). (Period 1: No capsules-no shredding; Period 2: Capsules-no shredding; Period 3: Capsules—-shredding)

in the reactor. Then the manual withdrawal of digestate from the reactor led to a decrease in this number down to $1.3 \times 10^{9} 16 \mathrm{~S}$ rRNA gene $\mathrm{g}^{-1}$ on week 16 . In the meantime, the number of bacteria in leachate remained stable at about $5.5 \times 10^{8} 16 \mathrm{~S}$ rRNA gene $\mathrm{mL}^{-1}$ confirming a poor transfer of microorganisms from the solid digestate to the leachate. The installation of the spraying stick induced an increase of the bacterial concentration in leachate that became closer to digestate concentration. Similar results are observed with the archaeal counts.

\section{Period 2: Optimizing with the Use of Perforated Capsules}

The second period, during which the feeding protocol changed and the capsule addition technique was experimented, started at the end of the 22nd week and lasted until the end of the 49th week. As expected, the use of capsules greatly eased the collection of solid digestate. But, in return, methane production and methane content significantly decreased to an average of respectively $97 \pm 67 \mathrm{~L} / \mathrm{kg}_{\mathrm{vs}}$ and $36 \pm 9 \%$ compared to the first period $(\mathrm{F}(1,308)=159$, $\mathrm{p}<0.05$ and $\mathrm{F}(1,42)=37, \mathrm{p}<0.05$ respectively) (Table 4). To counteract that loss of performances, several changes in leachate recirculation strategies were made such as increasing the volume of leachate recirculated, recirculate the leachate less or more often, but no significant improvements were recorded, neither for methane production nor methane content. According to the literature, this decrease in $\mathrm{AD}$ performances could be due to a lack of trace elements (TE). The analysis of $\mathrm{Fe}, \mathrm{Co}, \mathrm{Ni}$, Mo and Se contents in the leachate showed that each of them was lower than the expected optimal concentration or in the lower range of the optimal concentration (Table 3). Thus, at the beginning of week 34 , one liter of a nutrient solution prepared on site was added to the leachate tank to supplement the lack of TE. After the nutrient addition, TE contents finally reached the middle range of optimal concentrations (see Table 3) but no significant improvement of methane production was observed. However, nutrient addition positively impacted the quality of biogas. As shown in Fig. 3, from the moment the capsules were used, the biogas methane content almost continuously decreased from 51 to $21 \%$ (its lowest level) until nutrient addition. After nutrient addition, the methane content progressively increased for the next 4 weeks and stabilized at $33 \pm 3 \%$ until the end of the 2 nd period and even during the biogas leakage period.

These observations are in agreement with the microbial counts (Fig. 5). During period 2, the bacterial concentration in digestate and leachate remained close and relatively stable around respectively $1.3 \pm 1.1 \times 10^{10}$ gene $^{-1}$ and $4.9 \pm 4.5 \times 10^{9}$ gene $\mathrm{mL}^{-1}$. In contrast, the archaeal concentration strongly decreased by about 36 times in digestate and 90 times in leachate from week 23 to week 39. This decrease corresponds to the time when methane production constantly decreased (Fig. 3) suggesting that the archaeal growth was limited or inhibited during this period. Inhibition of archaea has been documented for low $\mathrm{pH}$, high ammonium concentration and nutrient limitation $[4,8,16]$. The increased archaeal counts and concomitant methane production recovery observed for digestate and leachate from week 40 to week 48 (Fig. 5) suggest that the most important factor was nutrient limitation and that recirculation of the "neutral" leachate through the acid solid digestate did not totally inhibited archaeal growth.

However, despite reaching final bacterial and archaeal counts similar to the one of period 1, results of the end of period 2 showed no significant enhancement of AD performances compared to the first period. One reason could be a lack of efficient leachate spreading inside the tubular reactor. Indeed, after their loading, FW rapidly stacked at the bottom of each capsule creating large head-space and thus preferential path for leachate circulation. In that way, leachate did not moisten the entire FW, slowing the degradation process and limiting a proper transfer of available solubilized organic matter in the leachate tank to end its degradation.

This hypothesis was confirmed by the assessment of VFA content in the leachate that significantly decreased from $2.0 \pm 1.9 \mathrm{~g} / \mathrm{kg}_{\mathrm{ww}}$ during period 1 to $0.7 \pm 0.8 \mathrm{~g} / \mathrm{kg}_{\mathrm{ww}}$ during period $2(\mathrm{~F}(1,137)=22, \mathrm{p}<0.05)$ while the total VFA content in the digestate remained stable $(\mathrm{F}(1,34)=1, \mathrm{p}>0.05)$ (Table 5A). In addition, in the digestate, a change in VFA composition occurred. During the first period, acetic and butyric acids were predominant with a respective average of $2.9 \pm 1.6$ and $3.0 \pm 2.2 \mathrm{~g} / \mathrm{kg}_{\mathrm{ww}}$. While the average acetic acid content remained stable during period $2(2.4 \pm 1.0 \mathrm{~g} /$ $\mathrm{kg}_{\mathrm{ww}}$ ), the butyric acid content significantly decreased to $1.3 \pm 0.9(\mathrm{~F}(1,34)=12, \mathrm{p}<0.05)$ (Table 5B). However, the average value of the $\mathrm{pH}(5.3 \pm 0.3)$ did not significantly 
varied compared to the first period, indicating a change in metabolic pathways due to the use of capsules.

\section{Period 3: Optimizing by FW Shredding}

The third period started at the end of the 49th week and lasted until the end of the 64th week. During that time, FW was shredded prior to its loading into the capsules. This change in protocol led to a significant increase of AD performances compared to the second period with an average methane production and methane content of $145 \pm 82 \mathrm{~L} / \mathrm{kg}_{\mathrm{vs}}$ and $45 \pm 6 \%$ respectively $(\mathrm{F}(1,268)=28, \mathrm{p}<0.05$ and $\mathrm{F}(1$, $41)=18, p<0.05$ respectively) (Table 4$)$. However, even if FW shredding positively impacted AD performances, they remained significantly lower than during the first period $(\mathrm{F}$ $(1,228)=27, \mathrm{p}<0.05$ and $\mathrm{F}(1,35)=6, \mathrm{p}<0.05$ respectively). A visual control of capsules showed that FW stacked again during the process but to a lesser degree. That time, no change in recirculation strategy was performed to enhance and reach the performances of the first period. Yet, from the end of the $57^{\text {th }}$ week, methane production was very unstable, varying from 55 to $320 \mathrm{~L} / \mathrm{kg}_{\mathrm{vs}}$ from one week to the next.

During this period, $\mathrm{pH}$ and VFA contents, and even microbial counts, in the leachate and the digestate showed no significant variations due to the shredding step, suggesting that the variations of methane production could be due to the variable physical-chemical characteristics of FW.

\section{Global Assessment of AD Performances}

Overall, the best performances were recorded during the first period. However, considering the mean biomethane potential (BMP) of FW (400 L/ $\mathrm{kg}_{\mathrm{vs}}$ according to Fisgativa et al. [16]), methane production reached only $50 \%$ of the theoretical methane yield during that period. Moreover, available data on two-stage $\mathrm{FW} \mathrm{AD}$ show that methane production usually varies between 391.6 and $728 \mathrm{~L} / \mathrm{kg}_{\mathrm{vs}}$ [31-33] compared to $200 \pm 78{ }_{N} \mathrm{~L} / \mathrm{kg}_{\mathrm{vs}}$ in this study. The low performances could be due to a dark fermentation process that often takes place during the mono-digestion of FW in two-stage systems according to the literature. In such cases, dark fermentation leads to the production of hydrogen that represents between 27 and $49 \%$ of the total biogas [34]. In this study, the hydrogen content measured all along week 28 and every week from the beginning of week 47 was $0.4 \pm 0.8 \%$, which is far below the values observed in the literature, proving that no dark fermentation took place during the experiment. Another possibility to explain the low AD performances could be linked to the substrate to inoculum ratio (S/I) usually considered as optimal at a value of $1\left(\mathrm{~kg}_{\mathrm{vs}} / \mathrm{kg}_{\mathrm{vs}}\right)[35,36]$. Moreover, Nasir et al. [37] experienced a process failure after 10 days of experiments during the anaerobic digestion of the organic fraction of municipal solid waste when applying a ratio of $6.5\left(\mathrm{~kg}_{\mathrm{vs}} / \mathrm{kg}_{\mathrm{vs}}\right)$. In comparison, the $\mathrm{S} / \mathrm{I}$ ratio of the micro-scale AD prototype along the experiment was very high with an average value of $7.4 \pm 3.2\left(\mathrm{~kg}_{\mathrm{vs}} / \mathrm{kg}_{\mathrm{vs}}\right)$. However, the quality of the inoculum in this study was equivalent to the previously cited authors in terms of VS content. Indeed, along the experiment, the average VS content of the leachate was $6.3 \pm 1.5 \%$ (wet weight) compared to 7 and $13 \%$ for Brown and $\mathrm{Li} \mathrm{[36]} \mathrm{and} \mathrm{Lee} \mathrm{et} \mathrm{al.} \mathrm{[35]} \mathrm{respectively.}$ Thus, the low AD performances measured could be due to an overloading of the micro-scale AD prototype. Finally, the global nitrogen mineralization rate was $47 \%$ without $\mathrm{NH}_{3}$ volatilization (nitrogen output to input ratio of 0.95 ) and about $49 \%$ of total VS was degraded with different efficiencies depending on the considered period (Table 4). In accordance with methane production, the first period had the highest VS removal efficiency with a mean value of 57\% while VS removal during AD of food waste usually ranges between 52 and 94\% [19].

All the results discussed above showed that the AD performances of the micro-scale AD prototype are below the theoretical and expected values found in the literature. Thus, the prototype and operation protocol must be improved to reach better methane yields and better organic matter degradation rates. The first and main challenge to improve $\mathrm{AD}$ performances consists in enhancing the hydric transfer between the tubular reactor and the leachate tank. One solution to be further tested consists in immerging completely and periodically the FW with leachate. The immersion step should favor the extraction of VFAs from the FW into the leachate. Moreover, in order to prevent process inhibition, nutritive solution should be added to the leachate at a frequency that still needs to be defined. With these improvements, AD performances should increase and stabilize to a better level without changing the specific design of the reactor.

\section{Microbial Community Analysis}

\section{Microbial Community Structure}

To get a better understanding of the process dysfunctions, in addition to the archaeal and bacterial counts, the microbial community structure of 15 digestates and leachates was characterized by $16 \mathrm{~S}$ rRNA gene high throughput DNA sequencing. A mean of 7972 sequences was obtained per sample that aggregated into 730 OTUs. The coverage percentage of sequencing is correct at $75 \% \pm 5 \%$ for digestate and $78 \% \pm 5 \%$ for leachate. The digestate and leachate at the start of the process contained respectively 171 and 164 OTUs (Fig S1). This number increased during the start-up phase of the reactor but stabilized thereafter around $241 \pm 31$ for digestate and $255 \pm 16$ for leachate. Calculation of the diversity indices (Shannon and Simpson indices) reveals a 
slightly higher and more stable microbial diversity for leachate than for digestate. Two values were particularly low for digestate on weeks 48 and 54 of period 3 suggesting either the extinction or the strong dominance of specific microbial populations during this period. However, no correlation is observed between the diversity indices variations and the process running parameters. This confirm a previous proposition by Goux et al. [38] that richness (OTU number) and diversity indices are not successful to predict process failure.

A Principal Coordinate Analysis ( $\mathrm{PCoA}$ ) of all microbial communities clearly separates the digestate communities from the leachate ones, confirming the selection of different microbial ecosystems in the tubular reactor and the leachate collection tank of the process (Fig S2). Actually, only two sampling times show similar microbial community structures between digestates and leachates. Week 7 after depletion of the inoculum reserves and week 50 when the reactor was emptied and restarted with shredded waste. These observations are in agreement with the conclusions drawn on process performances suggesting a real functional dissociation between the tubular reactor and the leachate tank.

\section{Microbial Community Composition and Putative Metabolic Pathways}

The Fig. 6 presents the taxonomic affiliation of the bacterial families whose relative abundance was higher than $5 \%$ of the total sequences in at least one sample and of all the archaeal genera identified. Clearly, the digestate and leachate exhibit different microbial communities from the start to the end of the experiment.

On day 0 , the microbial community of digestate is dominated by hydrolytic chemoorganotrophs such as Alcaligenaceae (24.2\% of total sequences) and Pseudomonadaceae (10.7\%) and fermentative groups such as Hungateiclostridiaceae (10.7\%) and Lactobacillaceae (7.7\%). The Archaea community represents only $0.3 \%$ of the retrieved sequences and is splited between two hydrogenotrophic methanogens, Methanosphaera (52.9\%) and Methanoculleus (47.1\%). Acetoclastic Archaea are not detected and the major methanogenic pathway seems thus being hydrogenotrophic. After 7 weeks of startup, the digestate community structure is completely different with the strong dominance of the genus Cloacimonas (37.9\%) from the Cloacimonadaceae, the Bacteroides from the Bacteroidaceae (14.8\%) and the uncultured DTU014 family (10.1\%). The Archaea community is dominated by the methylotrophic methanogen Candidatus Methanoplasma. Within this community structure, one can assume that Bacteroides and other hydrolytic bacteria degrade carbon sources into organic acids that are picked up by the acetogenic Cloacimonas and DTU014 families. Cloacimonas is an Obligate Hydrogen Producing Acetogen that degrades short chain fatty acids and particularly propionate sugars or amino acids into acetate, $\mathrm{CO}_{2}$ and $\mathrm{H}_{2}$ only when they are associated to hydrogen-scavenging microorganisms such as methanogenic, sulfate-reducing, and homoacetogenic bacteria [39, 40]. DTU014 are syntrophic acetate oxidizing bacteria that degrade acetate into $\mathrm{CO}_{2}$ and $\mathrm{H}_{2}$ in association with hydrogen-scavenging microorganisms [39, 40]. Candidatus Methanoplasma, which is an obligate hydrogen-dependent methylotrophic methanogen [41], is probably this scavenger. A third community structure is observed from weeks 12 to about 40 showing the dominance of fermentative bacteria such as Peptostreptococcales (up to $51.2 \%$ of the total bacteria on week 32 ), Lactobacillaceae, Clostridiaceae, and Streptococcaceae. The Streptococcaceae and Lactobacillaceae are lactic acid producers which dominance can be related to $\mathrm{pH}$ dropping (Fig. 4) and lactic acid accumulation (Table 5A). The dominant Archaea is Methanosphaera suggesting a metabolic shift back to hydrogenotrophy. Finally, a fourth community structure is observed from week 48 to the end of the experiment with a strong dominance of the lactic acid producer Lactobacillus (up to 77.4\%) associated with various Archaea of different metabolism including the first appearance of the versatile Methanosarcina able to perform methanogenesis by both acetoclastic and hydrogenotrophic pathways. This strong Lactobacillus dominance explains the low diversity indices observed above on weeks 48 and 54 (Fig S1). Within this period, week 50 appears as an outgroup. It corresponds to the time of process restart with shredded FW and mixing with recirculated leachate. At this time, the digestate and leachate microbial communities are similar.

The leachate microbial community dynamics is much more stable during the experiment (Fig. 6b). At the start of the process, the community is composed of various hydrolytic and acidogenic microbial groups such as Dysgonomonadaceae (20\%), Hungateiclostridiaceae (14.4\%), Erysipelatoclostridiaceae (12.7\%) and Lactobacillacaea (9.2). The VFA-oxidizing syntrophic families Cloacimonas and DTU014 are also present at respectively 8.6 and 3.1\%. The Archaea community is composed of the hydrogenotrophic Methanosphaera and Methanoculleus families and of the acetoclastic Methanosaeta. This microbial community structure is more typical of AD processes with two methanogenic pathways. The start-up phase of the process results in the enrichment of the Cloacimonas and DTU014 syntrophic bacteria associated to the methylotrophic methanogen $\mathrm{Can}$ didatus Methanoplasma, as it was the case for digestate. However, other hydrolytic and acidogenic bacteria such as the Rikenellaceae, Dysgonomonadaceae, Hungateiclostridiaceae and Spirochaetaceae remain present, as well as the hydrogenotrophic methanogens Methanoculleus and Methanosphaera. This bacterial community structure persists during all process operation, with a slight enrichment in the Rikenellaceae. This microbial family encompass several 
Fig. 6 Relative abundance and taxonomic identification of the bacterial and archaeal groups in digestate (a) and leachate

(b). (Period 1: No capsules-no shredding; Period 2: Capsules-no shredding; Period 3: Capsules—-shredding)

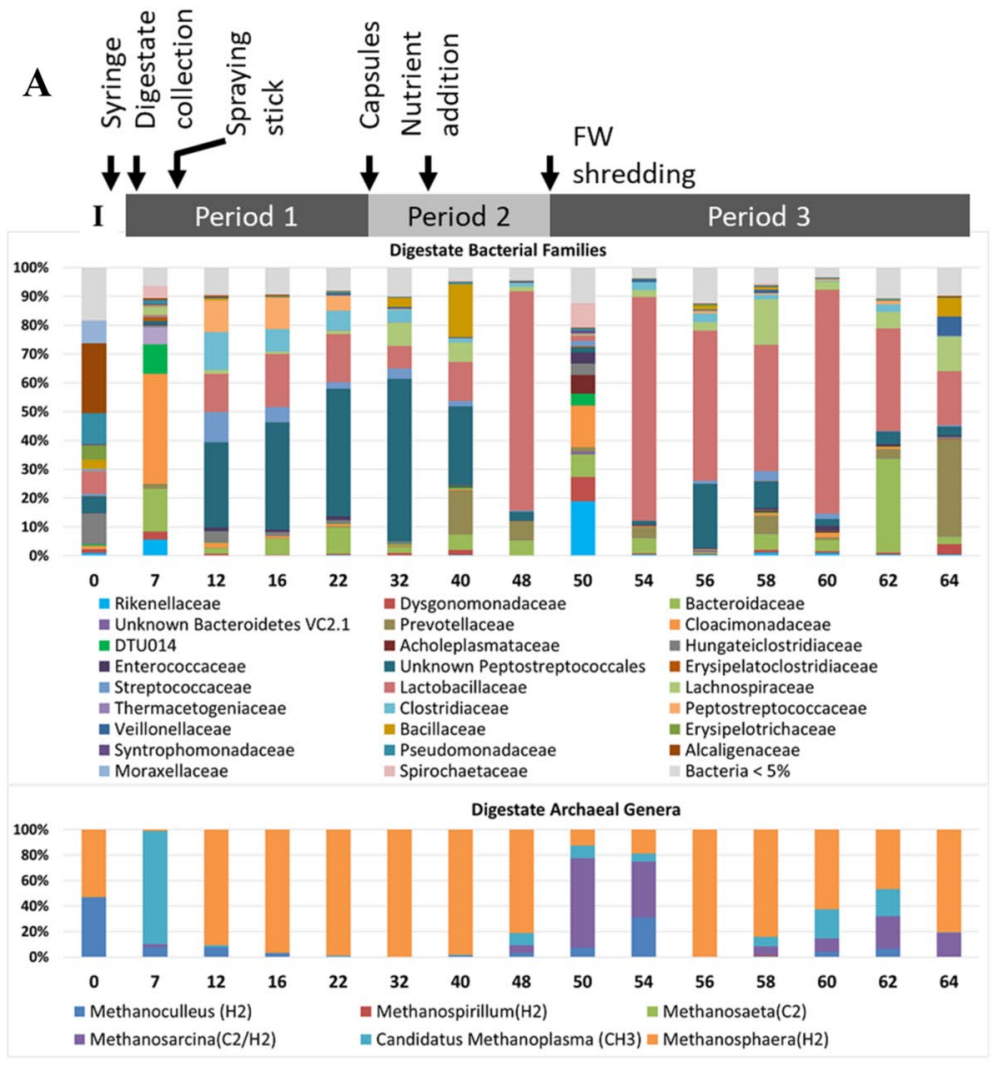

B
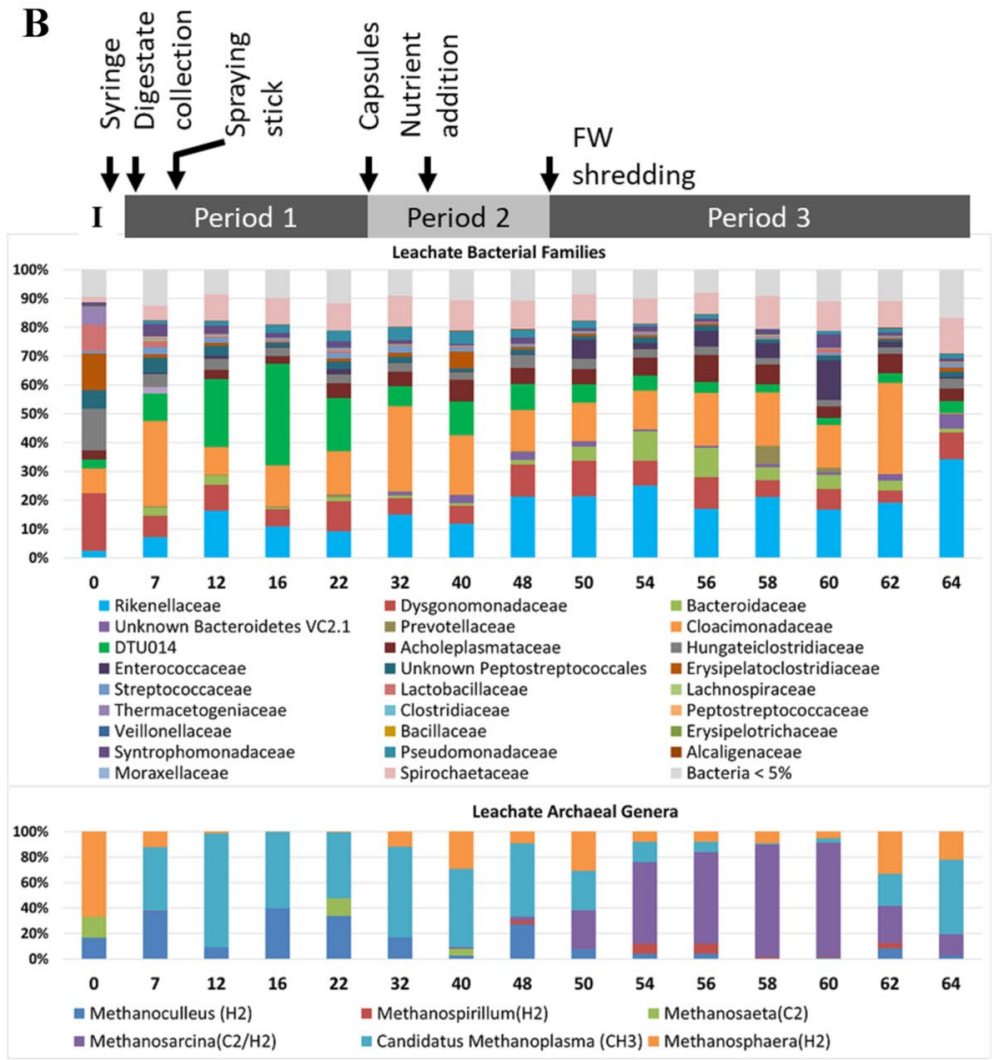
fermentative genera able to degrade complex carbohydrate and proteinaceous substrates to produce VFA including propionic and succinic acids. For the Archaea, the methylotrophic methanogen Candidatus Methanoplasma remains dominant along periods 1 and 2 with sometime the presence of the hydrogenotrophic Methanoculleus. Restart of the process on week 50 results in a change of this dominance since the major Archaea becomes the acetoclastic and hydrogenotrophic Methanosarcina.

Overall, these data show the development of an acidogenic microbial community within the tubular reactor dominated by the Peptostreptococcales and Lactobacillaceae microbial groups. The leachate bacterial community appears more stable and even than the digestate one. The hydrogenotrophic and methylotrophic pathways seem to be dominant for methanogenesis during periods 1 and 2 but the process operation during period 3 allows the dominance of the versatile Methanosarcina. Interestingly, the periods showing higher biogas methane content in Fig. 3 correspond to the presence of acetoclastic methanogens (Methanosaeta and Methanosarcina) in the leachate archaeal community (Fig. 6). This suggests a higher efficiency of methane production by the acetotrophic methanogens during process operation. Real time qPCR quantification (Fig S3a and b) confirmed that the count of hydrogenotrophic archaea was higher than the one of acetoclastic archaea, both for digestate and leachate, and during all process operation. However, only the evolution of the acetoclastic archaea concentration in leachate fitted well with biogas production and methane content.

\section{Conclusion}

This study investigated the anaerobic digestion performances of a novel and innovative solid-state micro-scale AD technology especially designed to degrade food waste in urban areas. The technology was designed to meet several challenges such as compactness, low energy and water demand. By including the phase separation inside the tubular reactor without using electrical devices, and with the high HRT of the leachate that avoid the addition of extra water in the system, the design successfully reached the objectives targeted.

However, the operation of the prototype was more challenging to reach high $\mathrm{AD}$ performances. Indeed, for all the experiment, two major problems were encountered: poor FW watering and acidosis. Chemical and microbiological data revealed the reactor was running as a two stages process operating FW hydrolysis, acidogenesis and acetogenesis within the plug flow tubular reactor, and probably further acidogenesis, acetogenesis and methanogenesis in the leachate tank. Insufficient watering of FW in the tubular reactor led to low hydrolysis, poor catchment of solubilized organic matter and digestate plugging in the reactor. In addition, shredding of FW induced strong acidosis in the tubular reactor that was probably stuck at the acidogenesis stage of $\mathrm{AD}$. Nevertheless, a positive issue was the strong stability of the $\mathrm{pH}$ of the leachate that allowed the microbial community to adapt and perform complete methanogenesis in the leachate tank.

In order to improve methane yields without changing the innovative design of the prototype, the complete immersion of FW with leachate, instead of simply recirculating the leachate through FW, could be a solution to improve the hydric transfer between the two stages of the micro-scale AD prototype.

Supplementary Information The online version contains supplementary material available at https://doi.org/10.1007/s12649-021-01555-2.

Funding This work is part of the DECISIVE project funded by the European Union's Horizon 2020 research and innovation program under grant agreement $\mathrm{N}^{\circ} 689229$.

\section{Declarations}

Conflict of interest The authors have no conflict of interest to declare that are relevant to the content of this article.

Data Availability All data and materials description can be published as they are.

Open Access This article is licensed under a Creative Commons Attribution 4.0 International License, which permits use, sharing, adaptation, distribution and reproduction in any medium or format, as long as you give appropriate credit to the original author(s) and the source, provide a link to the Creative Commons licence, and indicate if changes were made. The images or other third party material in this article are included in the article's Creative Commons licence, unless indicated otherwise in a credit line to the material. If material is not included in the article's Creative Commons licence and your intended use is not permitted by statutory regulation or exceeds the permitted use, you will need to obtain permission directly from the copyright holder. To view a copy of this licence, visit http://creativecommons.org/licenses/by/4.0/.

\section{References}

1. United Nations, D. O. E. A. S. A.: Population division. World Urbanization Prospects: The 2018 Revision. (2019)

2. Hoornweg, D.B.-T.: Perinaz. What a waste: a global review of solid waste management (2012)

3. Hoornweg, D., Bhada-Tata, P.: What a waste - A global review of solid waste management. World Bank. 116 (2012)

4. Zhang, C., et al.: Reviewing the anaerobic digestion of food waste for biogas production. Renew. Sustain. Energy Rev. 38, 383-392 (2014)

5. Wang, P., et al.: Microbial characteristics in anaerobic digestion process of food waste for methane production-A review. Biores. Technol. 248, 29-36 (2018) 
6. Campanaro, S., et al.: Metagenomic analysis and functional characterization of the biogas microbiome using high throughput shotgun sequencing and a novel binning strategy. (2016)

7. Kallistova, A.Y., et al.: Methane formation and oxidation by prokaryotes. Microbiology 86, 671-691 (2017)

8. Chen, Y., et al.: Inhibition of anaerobic digestion process: a review. Biores. Technol. 99, 4044-4064 (2008)

9. Garfí, M., et al.: Household anaerobic digesters for biogas production in Latin America: a review. Renew. Sustain. Energy Rev. 60, 599-614 (2016)

10. Castano, J.M., et al.: Performance of a small-scale, variable temperature fixed dome digester in a temperate climate. Energies 7, 5701-5716 (2014)

11. Lou, X.F., et al.: Field performance of small scale anaerobic digesters treating food waste. Energy Sustain. Dev. 16, 509-514 (2012)

12. Rajendran, K., et al.: Household biogas digesters-A review. Energies. 5, 2911-2942 (2012)

13. Chen, Y., et al.: Household biogas use in rural China: A study of opportunities and constraints. Renew. Sustain. Energy Rev. 14, 545-549 (2010)

14. Walker, M., et al.: Assessment of micro-scale anaerobic digestion for management of urban organic waste: a case study in London, UK. Waste Management. (2017)

15. Ademe. MODECOM 2017 - Campagne nationale de caractérisation des déchets ménagers et assimilés. 8 (2019)

16. Fisgativa, H., et al.: Characterizing the variability of food waste quality: a need for efficient valorisation through anaerobic digestion. Waste Manage. 50, 264-274 (2016)

17. Zhang, L., Jahng, D.: Long-term anaerobic digestion of food waste stabilized by trace elements. Waste Manage. 32, 1509-1515 (2012)

18. Capson-Tojo, G., et al.: Accumulation of propionic acid during consecutive batch anaerobic digestion of commercial food waste. Biores. Technol. 245, 724-733 (2017)

19. Srisowmeya, G., et al.: Critical considerations in two-stage anaerobic digestion of food waste - A review. Renew Sustain Energy Rev 119, 109587 (2020)

20. Voelklein, M.A., et al.: Role of trace elements in single and twostage digestion of food waste at high organic loading rates. Energy 121, 185-192 (2017)

21. APHA. Standard Methods for the Examination of Water and Wastewater, 22nd Edition. American Public Health Association, American Water Works Association, Water Environment Federation. (2012)

22. Bareha, Y., et al.: Characterization and prediction of organic nitrogen biodegradability during anaerobic digestion: a bioaccessibility approach. Biores. Technol. 263, 425-436 (2018)

23. Peu, P., et al.: Volatile fatty acids analysis from pig slurry using high-performance liquid chromatography. Int. J. Environ. Anal. Chem. 84, 1017-1022 (2004)

24. Yu, Y., et al.: Group-specific primer and probe sets to detect methanogenic communities using quantitative real-time polymerase chain reaction. Biotechnol Bioeng. 89, 670-679 (2005)

25. Farghaly, A., et al.: Effect of starvation period on microbial community producing hydrogen from paperboard mill wastewater using anaerobic baffled reactor. Environ. Technol. 40, 2389-2399 (2019)
26. Ince, B., et al.: Inhibition effect of isopropanol on acetyl-CoA synthetase expression level of acetoclastic methanogen, Methanosaeta concilii. J. Biotechnol. 156, 95-99 (2011)

27. Wang, Q., et al.: Naïve bayesian classifier for rapid assignment of rRNA sequences into the new bacterial taxonomy. Appl Environ Microbiol. 73, 5261-5267 (2007)

28. Wang, Y., Qian, P.-Y.: Conservative fragments in bacterial $16 \mathrm{~S}$ rRNA genes and primer design for 16S ribosomal DNA amplicons in metagenomic Studies. PLOS One 4, e7401 (2009)

29. Escudié, F., et al.: FROGS: Find, rapidly, OTUs with galaxy solution. Bioinformatics (Oxford, England). 34, 1287-1294 (2018)

30. McMurdie, P.J., Holmes, S.: phyloseq: an R package for reproducible interactive analysis and graphics of microbiome census data. PLOS One 8, e61217 (2013)

31. Paudel, S., et al.: Effect of volumetric organic loading rate (OLR) on $\mathrm{H} 2$ and $\mathrm{CH} 4$ production by two-stage anaerobic co-digestion of food waste and brown water. Waste Manage. 61, 484-493 (2017)

32. Pisutpaisal, N., et al.: Biological hydrogen and methane production in from food waste in two-stage CSTR. Energy Proced. 50, 719-722 (2014)

33. Ding, L., et al.: Investigating hydrothermal pretreatment of food waste for two-stage fermentative hydrogen and methane co-production. Biores. Technol. 241, 491-499 (2017)

34. Łukajtis, R., et al.: Hydrogen production from biomass using dark fermentation. Renew. Sustain. Energy Rev. 91, 665-694 (2018)

35. Lee, E., et al.: Biogas production from high solids anaerobic codigestion of food waste, yard waste and waste activated sludge. Waste Manage. 95, 432-439 (2019)

36. Brown, D., Li, Y.: Solid state anaerobic co-digestion of yard waste and food waste for biogas production. Biores. Technol. 127, 275$280(2013)$

37. Nasir, Z., et al.: Enhancing the hydrolysis process in a dry anaerobic digestion process for the organic fraction of municipal solid waste. Bioresou. Technol. Rep. 11, 100542 (2020)

38. Goux, X., et al.: Microbial community dynamics in replicate anaerobic digesters exposed sequentially to increasing organic loading rate, acidosis, and process recovery. Biotechnol Biofuels. 8 (2015)

39. Pelletier, E., et al.: "Candidatus Cloacamonas Acidaminovorans": genome sequence reconstruction provides a first glimpse of a new bacterial division. J. Bacteriol. 190, 2572-2579 (2008)

40. Mosbæk, F., et al.: Identification of syntrophic acetate-oxidizing bacteria in anaerobic digesters by combined protein-based stable isotope probing and metagenomics. ISME J. 10, 2405-2418 (2016)

41. Lang, K., et al.: New mode of energy metabolism in the seventh order of methanogens as revealed by comparative genome analysis of " $<$ span class=\&quot;named-content genus-species\&quot; id=\&quot;named-content $-1 \&$ quot; $>$ Candidatus $</$ span $>$ Methanoplasma termitum.” Appl. Environ. Microbiol. 81, 1338 (2015)

Publisher's Note Springer Nature remains neutral with regard to jurisdictional claims in published maps and institutional affiliations. 